\title{
USE OF LOPINAVIR/RITONAVIR ASSOCIATED WITH ERGOTAMINE RESULTING IN FOOT AMPUTATION: BRIEF COMMUNICATION
}

\author{
Fernando Raphael de Almeida FERRY, Guilherme Almeida Rosa DA SILVA, Rogerio Neves MOTTA, Ricardo de Souza CARVALHO \& Carlos Alberto Morais DE SÁ
}

\begin{abstract}
SUMMARY
A 32-year-old female, was diagnosed in 2004 with a C1 HIV1 infection, using zidovudine/lamivudine 300/150 mg BID and lopinavir/ritonavir 400/100 mg BID, in addition to prophylaxis with trimethoprim-sulfamethoxazole 800/160 mg QD, but no prophylaxis with macrolide antibiotics. The patient presented with a severe headache and was prescribed two capsules of the anti-migraine drug Ormigrein $^{\mathrm{TM}}$, which contained ergotamine tartrate $1 \mathrm{mg}$, caffeine $100 \mathrm{mg}$, paracetamol $220 \mathrm{mg}$, hyoscyamine sulfate $87.5 \mathrm{mcg}$, and atropine sulfate $12.5 \mathrm{mcg}$. Afterwards she was prescribed one capsule of Ormigrein every 30 minutes for a total of six capsules a day. The patient took the medication as prescribed but developed a pain in her left ankle three days later, which evolved to the need for amputation.
\end{abstract}

KEYWORDS: AIDS; Ritonavir; Antiretroviral; Pharmacological interactions.

MLS, a 32-year-old female, was diagnosed in 2004 with a C1 HIV1 infection (Centers for Disease Control classification). She discontinued her antiretroviral therapy (zidovudine, lamivudine and nevirapine) two years after starting the treatment and presented with the clinical manifestations of fever, dyspnea, appetite loss, diarrhea, anemia, weight loss, and severe asthenia. Her chest X-ray, arterial blood gases and lactate dehydrogenase levels were suggestive of pulmonary pneumocystis. Oral and vaginal candidiasis were also observed. She exhibited a good clinical response to treatment with trimethoprimsulfamethoxazole, fluconazole, corticosteroid and symptomatic drugs. We reintroduced highly active antiretroviral therapy (HAART) with zidovudine/lamivudine 300/150 mg BID and lopinavir/ritonavir 400/100 $\mathrm{mg}$ BID, in addition to prophylaxis with trimethoprim-sulfamethoxazole 800/160 mg QD, but no prophylaxis with macrolide antibiotics. Three weeks later, the patient presented with a severe headache at another institution, where physicians were not well trained in the management of AIDS patients. During the crisis, the patient was prescribed two capsules of the anti-migraine drug Ormigrein ${ }^{\mathrm{TM}}$, which contained ergotamine tartrate $1 \mathrm{mg}$, caffeine $100 \mathrm{mg}$, paracetamol $220 \mathrm{mg}$, hyoscyamine sulfate $87.5 \mathrm{mcg}$, and atropine sulfate $12.5 \mathrm{mcg}$. Afterwards she was prescribed one capsule of Ormigrein every 30 minutes for a total of six capsules a day. The patient took the medication as prescribed but developed pain in her left ankle three days later, which she self-treated with NSAIDs and a local application of ice.

As the symptoms worsened, she was admitted to our Hospital Medical AIDS Center. Her left lower limb on admission was cyanotic with cold, clammy skin and an absence of palpable pedal pulses. She was treated with an intra-arterial prostaglandin injection, followed by a synthetic prostaglandin analog given intravenously and sildenafil given by mouth, but only had a partial clinical response. Due to the ischemia of the distal vessels in her lower extremity and the necrosis of her left toes, a foot amputation at the metatarsal level was performed. ${ }^{4}$

Ritonavir is an anti-HIV protease inhibitor that was approved by the FDA in March of 1996. In vitro studies utilizing human liver microsomes demonstrated that major cytochrome P450 isoforms, mainly CYP3A4, CYP2D6 and CYP2C9/10, were involved in the metabolism of ritonavir. Currently, ritonavir is no longer used alone as a protease inhibitor in antiretroviral regimens. This drug is used in combination with lopinavir or another antiretroviral agent to increase the plasma levels of antiretroviral drugs by cytochrome inhibition ${ }^{1,2}$.

Thus, the reduction of the daily dose of ritonavir to $100-200 \mathrm{mg} /$ day was recommended in combination with regimens. In the protease inhibitor combination lopinavir/ritonavir, the dose of ritonavir $200 \mathrm{mg}$ daily is enough to increase plasma levels of lopinavir significantly. Therefore, caution is recommended when ritonavir is used in antiretroviral regimens, because coadministration with other drugs may be jeopardized on account of ritonavir competition for CYP3A4.

Ergotamine derivatives have partial agonist and antagonist activity against tryptaminergic, dopaminergic and alpha-adrenergic receptors, depending upon their binding site. Serious vasospasm and ischemia of

UNIRIO, Rio de Janeiro, RJ, Brazil. E-mails: ferry@unirio.br, drguialmeida@gmail.com, nevesmotta@gmail.com, ricardocarvalho@gmail.com, carlosalberto@gmail.com 
FERRY, F.R.A.; DA SILVA, G.A.R.; MOTTA, R.N.; CARVALHO, R.S. \& DE SÁ, C.A.M. - Use of lopinavir/ritonavir associated with ergotamine resulting in foot amputation: brief communication. Rev. Inst. Med. Trop. Sao Paulo, 56(3): 265-6, 2014.

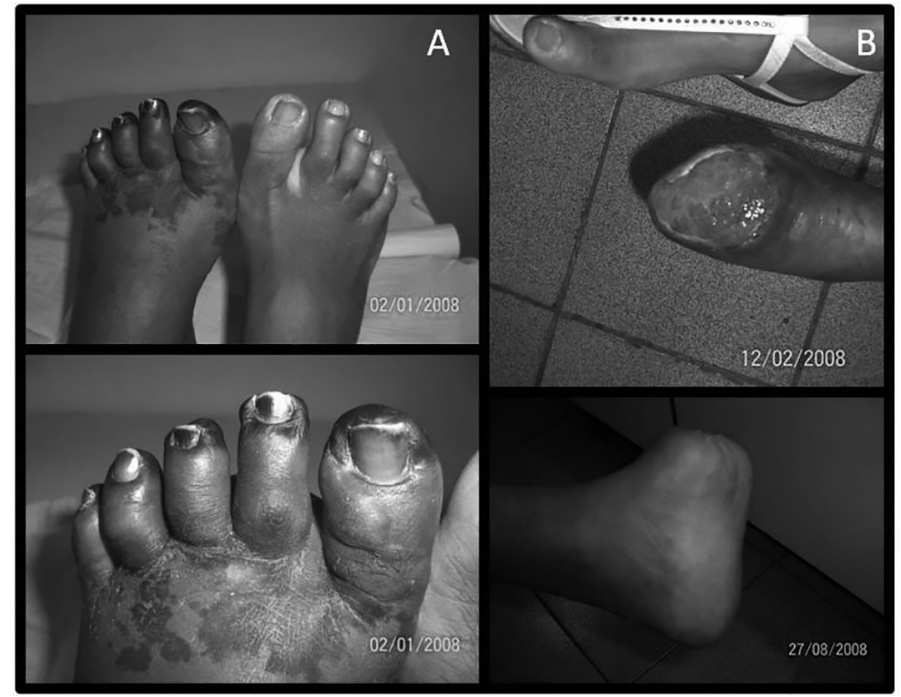

Fig. 1 - A - (Up and down) Left lower limb with cyanosis, necrosis, edema, and clammy skin. B - (Up and down) Left foot amputation at the metatarsal level.

the extremities and other tissues including the CNS have been observed with ergotamine derivatives.

The main indication of ergotamine is for the treatment of vascular headaches (migraine, migraine variants and histaminic cephalalgia). The effect of ergotamine may be potentiated by the concomitant use of drugs that inhibit the metabolism of cytochrome P450 3A4, such as ritonavir. The interaction of ergotamine with ritonavir has already been reported ${ }^{1,3}$, especially in cases when the daily dose of ritonavir reaches $1200 \mathrm{mg}$. In 2002, there was a report of a fatal case of ergot toxicity with ritonavir 200 mg daily, in which a combination of ergotamine with an antiretroviral regimen of stavudine, lamivudine and indinavir/ritonavir caused serious peripheral and cerebral vasoconstriction ${ }^{5}$.

\section{RESUMO}

Uso de lopinavir/ritonavir associado com ergotamina resultando em amputação de pé: comunicação breve

Mulher de 32 anos infectada pelo HIV 1, vinha utilizando zidovudina/ lamivudina 300/150 mg um comprimido duas vezes ao dia e lopinavir/ ritonavir 200/50 mg dois comprimidos duas vezes ao dia e profilaxia com sulfametoxazol-trimetoprim 800/160 mg uma vez ao dia, sem profilaxia com macrolídeos. A paciente apresentou enxaqueca severa com prescrição da associação tartarato de ergotamina 1 mg, cafeína 100 $\mathrm{mg}$, paracetamol $220 \mathrm{mg}$, sulfato de hiosciamina $87,5 \mathrm{mcg}$, sulfato de atropina $12,5 \mathrm{mcg}$, dois comprimidos na crise, seguido de um comprimido a cada 30 minutos, com no máximo seis comprimidos ao dia. A paciente ingeriu seis comprimidos em um dia, surgindo uma dor em tornozelo esquerdo três dias depois, que evoluiu para ergotismo e amputação do pé.

\section{REFERENCES}

1. Caballero-Granado FJ, Viciana P, Cordero E, Gomez-Vera MJ, del Nozal M, Lopez-Cortes LF. Ergotism related to concurrent administration of ergotamine tartrate and ritonavir in an AIDS patient. Antimicrob Agents Chemother. 1997;41:1207.

2. Kumar GN, Rodrigues AD, Buko AM, Denissen JF. Cytochrome P450-mediated metabolism of the HIV-1 protease inhibitor ritonavir (ABT-538) in human liver microsomes. J Pharmacol Exp Ther. 1996;277:423-31

3. Liaudet L, Buclin T, Jaccard C, Eckert P. Drug points: severe ergotism associated with interaction between ritonavir and ergotamine. BMJ. 1999;318:771.

4. Marine L, Castro P, Enriquez A, Greig D, Sanhueza LM, Mertens R, et al. Four-limb acute ischemia induced by ergotamine in an AIDS patient treated with protease inhibitors. Circulation. 2011;124:1395-7.

5. Tribble MA, Gregg CR, Margolis DM, Amirkhan R, Smith JW. Fatal ergotism induced by an HIV protease inhibitor. Headache. 2002;42:694-5.

Received: 13 August 2013

Accepted: 17 October 2013 